\title{
EQUITY
}

Vol. 24, No.2, 2021, 193-210

DOI: 10.34209 /equ.v24i2.3525

P-ISSN 0216-8545 | E-ISSN 2684-9739

Diunggah : November 2021

Diterima : Desember 2021

Dipublikasi : Januari 2022

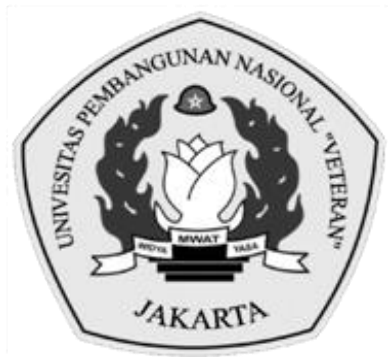

\section{ANALISIS ATRIBUTE AUDITOR DAN AUDIT REPORT LAG}

\author{
Wiwi Idawati* \\ wiwi.idawati@ibs.ac.id \\ Sekolah Tinggi Ilmu Ekonomi Indonesia Banking School \\ *Penulis Korespondensi
}

\begin{abstract}
Abstrak
Penelitian ini bertujuan untuk menguji audit report lag dengan beberapa faktor yang mempengaruhinya seperti komite audit, rotasi audit dan ukuran KAP dengan ROA dan DER sebagai variabel kontrol pada periode 2018 sampai dengan tahun 2020 pada perusahaan pertambangan. Jenis penelitian adalah kausalitas sedangkan data yang digunakan adalah data skunder serta alat analisis data menerapkan Eviews 9 sebagai aplikasi dalam penelitian. Populasi pada perusahaan ini adalah seluruh perusahaan tambang sebanyak 41 dan terdaftar di BEI selama tahun 2018 sampai dengan 2020 dengan teknik penarikan sampel adalah purposive sampling sebanyak 24 perusahaan. Hasil penelitian ini menyatakan rotasi audit serta ukuran KAP memiliki pengaruh dan variabel yang tidak memiliki pengaruh terhadap audit report lag yaitu komite audit.
\end{abstract}

Kata Kunci: Audit Report Lag; Rotasi Audit; Ukuran KAP; Komite Audit

\begin{abstract}
This study aims to examine audit report lag with several influencing factors such as audit committee, audit rotation and KAP size with ROA and DER as control variables in the period 2018 to 2020 in mining companies. The type of research is causality while the data used are secondary data and the data analysis tool applies Eviews 9 as an application in the study. The population of this company is all 41 mining companies and listed on the IDX during 2018 to 2020 with a sampling technique of 24 companies using purposive sampling. The results of this study state that audit rotation and KAP size have an influence and a variable that has no effect on audit report lag is the audit committee.
\end{abstract}

Keywords: Audit Report Lag; Audit Rotation; KAP Size; Audit Committee

\section{PENDAHULUAN}

Manajemen perusahaan menyajikan laporan keuangan kepada para investor yang merupakan tanggung jawabnya dalam mengelola dana yang telah diberikan untuk mengembangkan aset perusahaan diharapkan menghasilkan profit untuk entitas. Informasi yang dapat diperbandingkan, dapat diverifikasi, mudah dipahami dan tepat waktu merupakan patokan dari sebuah laporan keuangan yang baik dan berkualitas (Jaori \& Mulyani, 2018). Perusahaan sebaiknya tidak menunda penyajian dan pelaporan keuangannya agar informasi yang ada tetap relevan dan akurat untuk dijadikan acuan sebagai decision making. Berdasarkan PSAK No. 1 pada 
tahun 2019 menyatakan setiap unit bisnis wajib menyajikan laporan keuangan sebagai sumber komunikasi bisnis bagi entitas yang berkepentingan dengan tujuan sebagai sarana penyampaian informasi sehingga dapat dipahami oleh pengguna sebagai dasar pengambilan keputusan bisnis entitas. Dengan demikian financial reporting dapat diverifikasi oleh eksternal auditor untuk memberikan pemahaman bahwa financial reporting sudah disusun berdasarkan internasional financial reporting standar (IFRS).

Pihak regulator merupakan kementerian keuangan mengeluarkan ketentuan PMK Nomor. 17-PMK.01-2008 dari menteri keuangan terkait Jasa Profesional Akuntan Publik. Untuk sasaran pemerintah mengeluarkan peraturan ini adalah untuk melindungi kepentingan umum. Pengawasan melalui undang-undang ini mengharapkan bahwa kualitas jasa Kantor Akuntan Publik sebagai pemberi jasa yang kompeten dan objektif dan hal ini yang motivasi bagi KAP untuk meningkatkan profesionalisme yang tinggi (Arens et al 2012).

Peningkatan Profesional dari seorang auditor sangat diperlukan terutama dalam menyampaikan hasil pemeriksaannya yang berdampak pada keterlambatan penyampaian laporan keuangan. Berdasarkan ketetapan Bapepam No. 36/PM/2003 mengenai ARL untuk setiap entitas bisnis di BEI harus menyajikannya berdasarkan standar akuntansi keuangan disertai dari hasil pemeriksaan berdasarkan internasional standar auditing.

Berdasakan SK Direksi Nomor 00015/BEI/01-2021 terkait perihal Kewajiban Penyampaian Informasi yang berlaku sejak 1 Februari 2021, dimana penyampaian Laporan Keuangan Auditan dibatasi yaitu bulan ketiga atau selama 90 hari setelah tanggal neraca. Apabila perusahaan hingga akhir bulan ke-3 belum menyampaikan laporan keuangannya, maka dapat dikenakan sanksi. Selanjutnya dalam Pasal 7 ayat 1 aturan POJK No. 29/POJK.04/2016 tentang Laporan Tahunan Emiten menyatakan bahwa Laporan keuangan harus memiliki pertanggungjawaban Direksi serta Dewan Komisaris untuk mengutus dan mengawasi emiten publik dalam jangka waktu 1 (satu) tahun buku kepada RUPS. Pada kenyataannya meskipun sanksi yang akan diperoleh sudah jelas tidak memungkiri terdapat emiten dalam menginformasikan laporan keuangan ke OJK telat dari jangka waktu yang ditetapkan. Peneliti (Indra \& Arisudhana, 2012) mengatakan bahwa dalam melakukan pembuktian atas informasi yang terdapat didalam Financial Reporting, dimana waktu yang dibutuhkan auditor cukup lama dalam penyelesaian penugasan auditnya dan mengakibatkan penyampaian laporan keuangan akan mengalami keterlambatan.

Bursa Efek Indonesia setiap tahunnya mengeluarkan pengumuman terkait informasi keterlambatan Penyampaian Laporan Keuangan Per tanggal 29 Juni 2018 Bursa Efek Indonesia akhirnya melakukan suspensi pada sepuluh entitas yang terdeteksi per 31 Desember 2017 tidak melaporkan laporan keuangan audit dan sanksi atas denda yang diberikan (CNBC Indonesia, 2018). Pada tahun berikutnya per 31 Desember 2018 ditemukan sepuluh perusahaan tidak melakukan penyampaian serta membayarkan denda sehingga terjadi pemberhentian sementara atau suspensi kepada entitas terkait (Liputan6, 2019). Lalu di tahun 2020 Bursa juga mencatat ditemukan 26 entitas yang belum melakukan penyampaian dan belum membayarkan denda keterlambatannya (CNBC Indonesia, 2020). 
Tabel 1. Daftar Emiten telat menginformasikan laporan keuangan auditan

\begin{tabular}{llll}
\hline No & Tahun & Jumlah Perusahaan & Sanksi Keterlambatan \\
\hline \multirow{2}{*}{1} & \multirow{2}{*}{2017} & 2 & Penghentian Sementara \\
& & 8 & Suspensi Perdagangan \\
2 & 2018 & 4 & Penghentian Sementara \\
& & 6 & Suspensi Perdagangan \\
3 & 2019 & 9 & Penghentian Sementara \\
& & 17 & Suspensi Perdagangan \\
\hline
\end{tabular}

Sumber: www.idx.co.id (2021)

Pada tabel ini menggambarkan adanya emiten yang telat menginformasikan laporan keuangan diantaranya perusahan pertambangan. Adapun perusahaan pertambangan tersebut dapat dijelaskan pada tabel. 2 .

Tabel 2. Daftar Perusahaan Sektor Pertambangan yang terlambat menyampaikan Laporan Keuangan Auditan periode 2017-2019

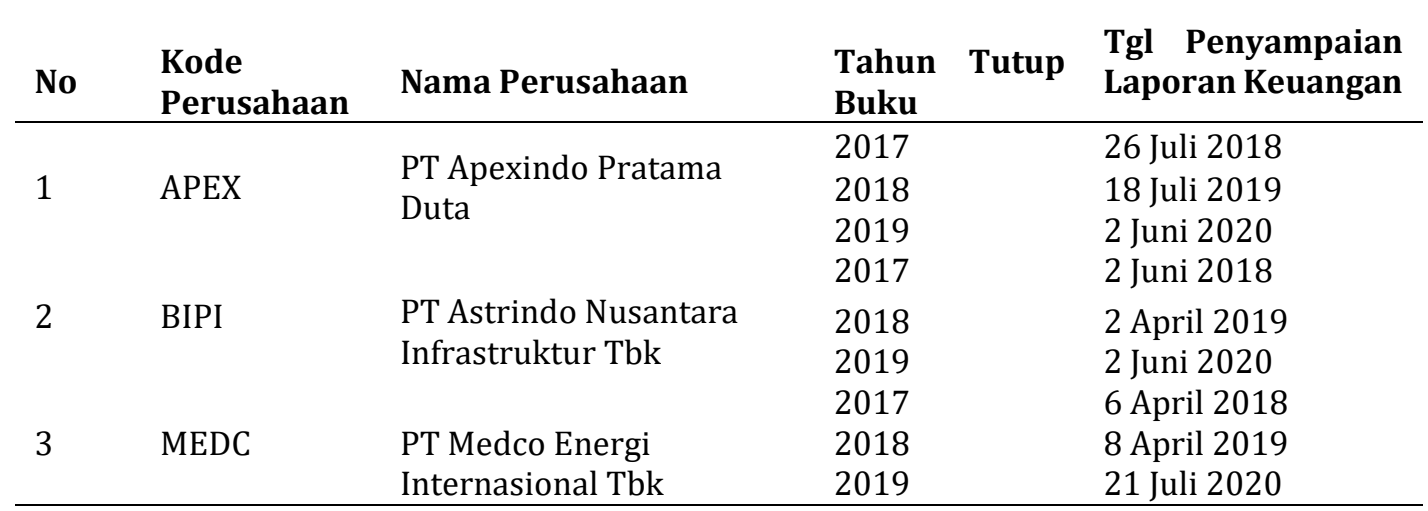

Sumber: data diolah (2021)

Pada tabel diatas memperlihatkan dimana ketiga perusahaan tersebut secara terus-menerus selama tiga tahun terlambat dalam penyampaian laporan keuangan auditannya. Dimana melebihi batas penyampaian sudah ditetapkan yaitu 90 hari. Akibatnya, perusahaan-perusahaan yang terlambat ini akan diberikan peringatan oleh Bursa Efek Indonesia. Sebanyak 3 Peringatan dengan tenggat waktu berbeda telah ditentukan oleh Bursa. Jika perusahaan belum juga menyampaikan laporan keuangannya, ada sanksi berupa denda sesuai berapa lama perusahaan terlambat menyampaikan laporan keuangannya. Bahkan perusahaan tercatat bisa dikenai suspensi atau pemberhentian perdagangan untuk sementara waktu hingga perusahaan membayar sanksi denda yang diberikan.

Menurut Knechel dan Vanstrelen (2007) pada penelitian Rahmat dan Hendarjatno (2019) Rotasi audit adalah waktu penugasan audit. Dengan adanya aturan tersebut, dapat dijelaskan bahwa jangka waktu perikatan audit harus dibatasi agar dapat meminimalisir timbulnya berbagai risiko yang dapat muncul. Salah satu risiko yang berkemungkinan muncul adalah berkurangnya independensi dari auditor. Jika independensi dari auditor tersebut berkurang maka opini yang dihasilkan oleh auditor tersebut akan keliru dan tidak dapat menggambarkan keadaan laporan keuangan yang sebenarnya dengan demikian adanya SDM yang berkualitas serta sistem yang canggih, The big Four memiliki kemungkinan untuk 
meng-audit Laporan Kuangan lebih cepat. Dalam penelitian ini penulis mengkategorikan KAP kedalam 2 jenis, yaitu KAP Big four dan KAP Non Big Four. Selanjutnya faktor yang dapat mempengaruhi Audit Delay yaitu Ukuran Komite Audit. Menurut POJK No.55/P0JK.04/2015 Pasal 4 Komite Audit paling sedikit terdiri atas 3 (tiga) anggota yang berasal dari komisaris Independen dan pihak dari luar emiten atau perusahaan publik.

\section{TINJAUAN PUSTAKA}

\section{Teori Agensi (Agency Theory)}

Theory Agency diartikan sebagai pertentangan keinginan owner dengan manager. Manajemen menganggap bahwa perusahaan yang dikelola merupakan bagian dari keberhasilan mereka melaksanakan tugas dan tanggung jawabnya sehingga menjadi perusahaan yang berkembang dan berkelanjutan (Jensen, \& W. Meckling 1976.). Manajemen terkadang menjalankan kebijakan yang tidak diharapkan diharapkan oleh investor sehingga konflik keagenan yang adanya pembagian tugas antara pemilik dengan manajemen akan menimbulkan konflik (Graham \& Tucker, 2006). Kualitas informasi yang dihasilkan oleh manajamen merupakan hal yang tidak bisa dihindari agar dapat mengurangi asimetris informasi.

\section{Compliance Theory (Teori Kepatuhan)}

Berdasarkan aturan No.29/POJK.04/2016 pasal 7 menyatakan entitas diwajibkan melaporkan selambat-lambatnya pada bulan ke empat terkait laporan keuangan auditan.

Compliance theory ini memiliki dua perspektif antara lain instrumental dan normatif. Dalam perspektif instrumental menyebutkan bahwa kepentingan pribadi didorong oleh individu secara mandiri dan argument yang berhubungan dengan perilaku. Sedangkan sebaliknya, didalam perspektif normatif seseorang akan mementingan nilai moral dibandingkan dengan kepentingan pribadi individu bisa diartikan mereka patuh karena hal tersebut dianggap sebagai keharusan dalam mematuhi peraturan otoritas penyusun hukum tersebut, yang dinyatakan oleh (Sulistyo, 2010).

\section{Audit Report Lag}

Menurut Carslaw and Kaplan, 1991; Bamber et al., 1993 dalam Muhammad et al., (2019) menyatakan bahwa lamanya hari yang diperlukan untuk menyelesaikan proses audit atas laporan keuangan perusahaan setelah tanggal tutup buku perusahaan. Sementara menurut (Ryu dan Roh, 2007) dalam Rahmat dan Hendarjatno, (2019) Audit Lag adalah jarak antara tanggal neraca per 31 Desember sampai tanggal penerbitan laporan audit. Selanjutnya Knechel dan Payne (2001) dalam Siwy (2012) menyatakan bahwa audit report lag dibedakan menjadi; Scheduling lag yaitu rentang waktu antara tahun tutup buku emiten dengan waktu dimulainya pekerjaan lapangan auditor. Reporting lag dimana tanggal penyelesaian pekerjaan lapangan terdapat selisih waktu dengan tanggal laporan auditor. Fieldwork lag merupakan waktu dimana pekerjaan lapangan dan saat penyelesaiannya. 
Dalam penelitian Meckfessel dan Sellers (2017) ARL diukur sebagai waktu yang telah berlalu dari tahun fiskal klien berakhir sampai tanggal auditor menandatangani laporan mereka.

\section{Audit Rotasi}

Arens (2012) bahwa rotasi audit adalah sebagaimana yang diwajibkan oleh Sarbanes - Oxley Act, aturan independensi mensyaratkan untuk merotasi Akuntan Publik setelah lima tahun dan KAP setelah tujuh tahun dan Chi et al (2004) menyatakan bahwa rotasi audit adalah pergantian KAP karena jasa audit yang dilaksankan dengan klien. Kebijakan dari Kemenkue Nomor: 17/PMK.01/2008 yang menjelaskan bahwa "Pemberian jasa audit umum atas laporan keuangan dari suatu entitas sebagaimana dimaksud dalam Pasal 2 ayat (1) huruf a dilakukan oleh KAP paling lama untuk 6 (enam) tahun buku berturut-turut dan oleh seorang Akuntan Publik paling lama untuk 3 (tiga) tahun buku berturut-turut".

\section{Audit Firm Status}

Organisasi bisnis akuntan publik yang memberikan jasanya secara profesional dalam praktek sebagai pihak yang independen dan mendapatkan persetujuan berdasarkan kebijakan regulator yang berlaku disebut Kantor Akuntan Publik (KAP) (Rachmawati, 2008 dalam (Yuanisa, 2018). Dalam upaya penyampaian laporan keuangan secara terbuka, perusahaan tentu saja membutuhkan jasa auditor independen untuk memeriksa laporan keuangannya. Sebab, Finansial Reporting yang diberikan opini oleh auditor lebih diakui kualitas serta kredibilitasnya. Kualitas dan kredibilitas yang dihasilkan tentu lebih dipercayai publik apabila perusahaan menyewa jasa KAP yang bereputasi atau memiliki nama yang baik (Putri et al., 2018). Reputasi KAP menandakan kadar kepercayaan khalayak umum pada suatu kantor akuntan publik atas image yang melekat auditor tersebut (Maharani et al., 2020), Selanjutnya Menurut (Sunarto et al., 2021) biasanya KAP dengan mengantongi image sebab berafiliasi dengan KAP yang dikenal luas dan besar atau yang termausk dalam kategori the big four.

Tingginya image pada perkembangan KAP yang dipakai oleh emiten, maka laporan keuangan yang disampaikan lebih tepat waktu. Sebab financial reporting yang sudah diperiksa oleh the big four oleh masyarakat beserta investor lebih dipercaya bahwa laporan keuangannya telah diaudit dan terverifikasi dengan semestinya. Sehingga hal ini memicu perusahaan dalam menyampaikan laporan keuangannya secepat mungkin (Sunarto et al., 2021)

\section{Audit Committee}

Audit Committee merupakan personel yang terpilih diantara jajaran direktur dengan kualifikasi untuk mengawasi eksternal auditor dalam menjaga indepedensi di manajemen serta memberi jaminan bahwa laporan keuangan dapat diandalkan (Menurut (Arens et al., 2015, p. 786). Komite audit yang dimaksudkan adalah mempunyai beground finance serta accounting Karena audit committee berperan penting untuk menetapkan keputusan yang tepat dalam mengawasi tindakan manajemen, standar audit Public Company Accounting Oversight Board (PCAOB) mewajibkan auditor dari entitas dalam meningkatkan efisiensi dan efektivitas atas internal control. 
Selain bertugas mengawasi serta mengevaluasi hasil audit, menurut (Tugiman, 1997) komite audit juga memiliki beberapa tugas terhadap laporan keuangan, yaitu:

1) Berdiskusi dengan auditor dan manajemen mengenai dasar akuntansi yang diterapkan, serta berdiskusi mengenai kebijakan aplikasi dalam mempersiapkan laporan keuangan apabila ada masalah luar biasa yang akan menjadi pertanyaan diakhir tahun. Oleh karena itu, komite audit harus menyiapkan rincian ikhtisar keuangan dengan lengkap dan factual.

2) Mengamati perubahan akuntansi dimasa sekarang dan dimasa yang akan datang, jika perubahan tersebut memberikan pengaruh terhadap hukum perusahaan maka perubahan itu harus dilaporkan kepada dewan komisaris.

3) Menelaah kuartal dan tahunan terhadap ikhtisar keuangan sebelum laporan keuangan perusahaan diserahkan kepada Dewan Komisaris.

Berdasarkan beberapa tugas yang dikerjakan oleh Komite Audit dengan jumlah lebih banyak menunjukan lebih cepat ketika mengerjakan proses audit laporan keuangannya. Hal ini dapat terjadi karena audit committee mempunyai internal control yang efektif dalam menurunkan tingkat keterlambatan penyampaian laporan keuangan. Oleh sebab itu, dalam penelitian ini sesuai dengan penelitian (Maggy \& Diana, 2018) komite audit diproksikan menggunakan proporsi komite audit dengan Rumus 1 berikut ini

\section{Rumus 1. Rumus Perhitungan Jumlah Komiter Audit}

Proporsi Komite Audit = Jumlah Komite Audit

Dalam penelitian (Nabila \& Daljono, 2013) Proporsi komite audit akan menggambarkan tingkat kinerja komite audit. Apabila jumlahnya lebih besar, maka kinerjanya akan meningkat dan fungsi pengawasan juga semakin meningkat.

\section{Profitabilitas}

Kinerja keuangan yang dapat mengukur tingkat kepastian dalam mencapai laba yang tinggi sering menggunakan Return on Asset Sartono (2010:122). ROA yang rendah akan menurunkan kemampuan perusahaan untuk aktif dalam pasar. Dapat dikatakan, jika keuntungan yang diperoleh oleh sebuah perusahaan merupakan good news dimana perusahaan cenderung enggan melakukan penundaan dalam penyampaian laporan keuangannya (Fauziah et al., 2020). Return on Asset menunjukan besarnya efektivitas laba yang diperoleh dari pendapatan operasional perusahaan dan invetasi. Dengan demikian ROA dapat menunjukan entitas dalam meningkatkan laba dari asset yang digunakan. Berikut ini rumus perhitungan ROA ditampilkan dalam Rumus 2.

Rumus 2. Rumus Perhitungan ROA

$$
R O A=\frac{\text { Laba bersih setelah Pajak }}{\text { Total Aset }}
$$

\section{Leverage}

Merupakan pengaplikasian asset dan sumber dana perusahaan yang mempunyai biaya tetap yang memiliki tujuan agar dapat menambahkeuntungan 
potensial shareholder (Sartono, 2008). Oleh karena itu, Leverage dapat dipakai dalam menghitung kesanggupan entitas agar dapat memenuhi seluruh hutangnya jika suatu perusahaan akan mencapai tingkat likuidasi.

Dalam (Fahmi, 2014) menyebutkan bahwa rasio leverage atau solvabilitas merupakan kemampuan perusahaan dalam mengelola tingkat hutangnya agar dapat memiliki keuntungan serta agar mampu untuk melunasi hutang-hutangnya kembali. Perusahaan yang tidak dapat melunasi hutangnya kembali dapat disebut sebagai perusahaan yang tidak solvable, dikatakan seperti itu karena pada perusahaan tersebut jumlah kewajibannya lebih besar daripada jumlah aktivanya. Dengan ini akan menyebabkan semakin tinggi leverage maka semakin tinggi juga kerugian yang terjadi dan akan menghambat perusahaan untuk menginformasikan laporan keuangan auditan kepada 0JK.

Rasio Leverage merefleksikan kemampuan perusahan dalam memenuhi utang jangka panjangnya. Untuk itu rasio leverage dapat digolongkan menjadi (Kuswadi, 2008); Debt-to-Assets Ratio (DAR), Merupakan ratio untuk menghitung apakah perusahaan mampu atau tidak dalam mengelola hutangnya dengan aset yang dimilikinya. Debt-to-Equity Ratio (DER), Menunjukan jumlah utang entitas terhadap jumlah equity perusahaan. Rasio kewajiban jangka Panjang atas kapitalisasi.

Emiten yang nilai kapitalisasi tinggi cenderung memiliki kewajiban yang besar dibandingkan dengan entitas yang sebaliknya. Dimana perusahaan dengan kapitalisasi kecil berarti mampu melunasi hutangnya sendiri tanpa menggunakan modal perusahaan yang banyak.

Dalam penelitian (Prastiwi et al., 2018) Leverage digunakan dalam menghitung jumlah hutang dalam mendanai entitas. Apabila entitas mempunyai tingkat leverage tinggi berarti resiko entitas mengalami kerugian semakin besar. Hal ini berpengaruh dalam penyelesaian penerbitan laporan keuangan auditan dimana penyampaiannya bisa jadi tidak tepat waktu. Oleh karena itu, DER menurut Subramanyam \& Wild, 2013, p. 36 dengan rumus 3 dibawah ini

Rumus 3. Rumus Perhitungan DER

$$
\text { DER }=\frac{\text { Total Hutang }}{\text { Total Ekuitas }} \times 100
$$

\section{Pengaruh Rotasi Audit terhadap Audit Report Lag}

Menurut hasil penelitian Mai Dao et al (2014) mereka menemukan beberapa bukti rotasi audit yang pendek berpengaruh terhadap ARL yang lebih lama, berarti Rotasi Audit memiliki pengaruh terhadap Audit Report Lag. Selain itu menurut penelitian Wan Nordin Wan Hussin et al (2018) keterikatan partner dengan beban kerja yang berat dapat memitigasi dampak buruk dari ketepatan waktu dari melaporkan laporan audit secara tepat waktu ketika mereka memiliki client tenure yang lebih lama, yang artinya adalah Audit Tenure berpengaruh Negatif terhadap Audit Repor Lag. Dari hasil penelitian terdahulu, maka penulis mengajukan hipotesis yaitu:

\section{H1: Rotasi audit berpengaruh negatif terhadap Audit report lag.}


Gambar 1. Kerangka Pemikiran

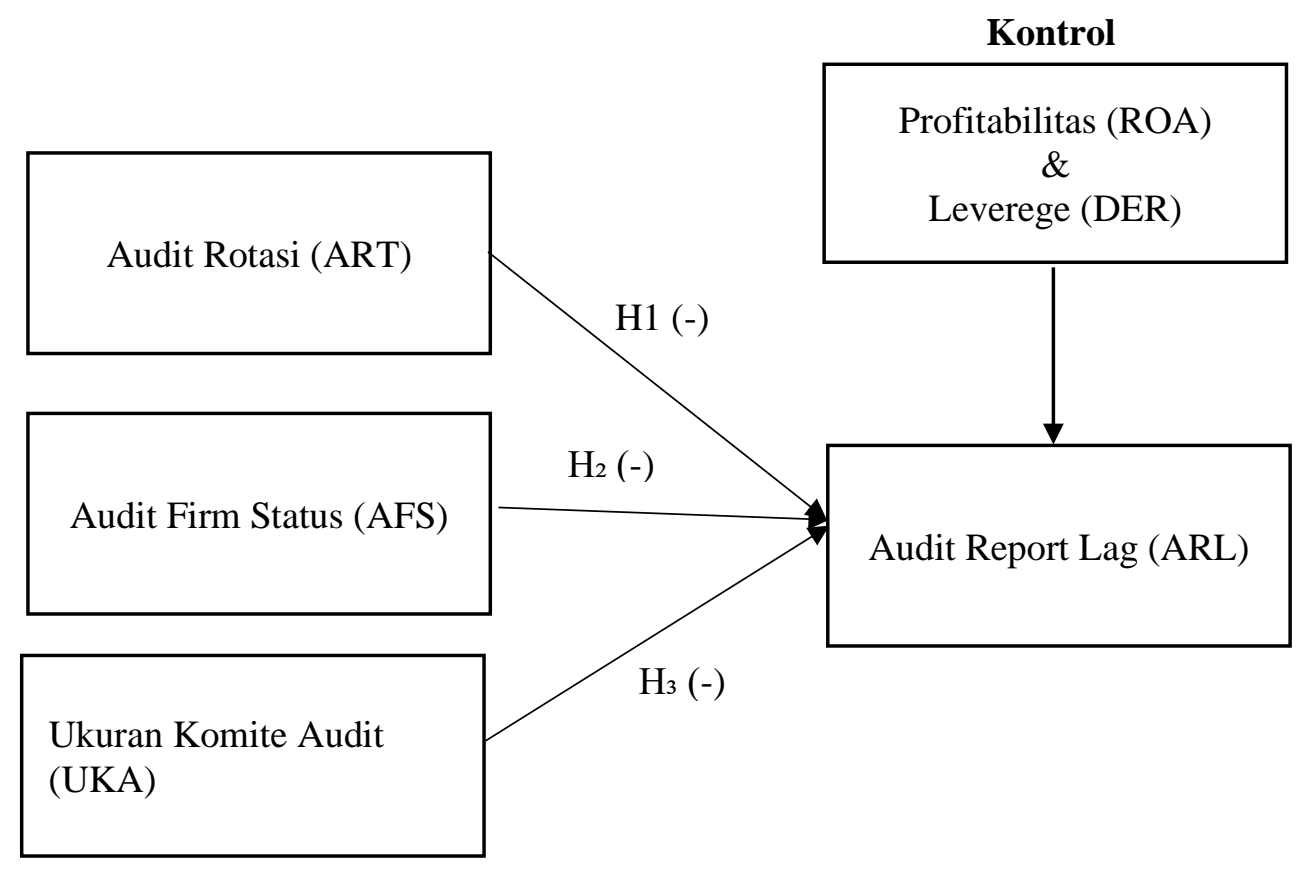

Sumber: Data Penelitian (2021)

\section{Pengaruh Audit Firm Status terhadap Audit report lag}

Berdasarkan UU nomor 5 tahun 2011 tentang KAP menyatakan sebagai unit usaha yang di bidang jasa Assurance maupun non-assurance. Dalam pengelompokan KAP dibedakan ke dalam Big Four maupun Non Big Four. Menurut Rizki dan Basuki (2017) untuk the Big Four lebih tepat waktu dalam menyelesaikan penugasannya dan mempunyai pelatihan 200ariab audit yang lebih tinggi disertai tingkat kompetensi teknologi yang canggih dibandingkan yang KAP Non Big four sehingga ukuran KAP yang lebih besar memiliki pengaruh terhadap terjadinya ARL.Menurut penelitian Meckfessel et al (2017) bahwa ukuran KAP memiliki pegaruh positif dan signifikan secara 200ariable200 terhadap audit report lag dan restatement rate. Sementara menurut penelitian Pinta Uli (2014) KAP Big Four memiliki pengaruh 200ariable signifikan terhadap audit report lag. Maka dari itu penulis mengajukan hipotesis yaitu

\section{lag.}

H2: Audit Firm Status berpengaruh 200ariable terhadap Audit report

\section{Pengaruh Ukuran Komite Audit terhadap Audit Report Lag}

Dalam penelitian ini audit committee yang dimaksudkan yaitu jenis Komite Audit mempunyai latar belakang kompetensi dibidang Finance dan Accounting Komite audit merupakan anggota yang terpilih dari klien dewan direktur yang bertugas mendampingi auditor dalam menjaga independensi terhadap entitas dan juga menjamin tingkat kepercayaan pemakai laporan keuangan atas informasi keuangan yang disajikan oleh entitas. (Arens, 2016; 105). Komite audit ditugaskan untuk memantau penerapan evaluasi hasil audit dalam penyusunan laporan keuangan. 
Berdasarkan Peraturan Otoritas Jasa Keuangan Nomor 55/POJK.03/2016 pasal 34 mengatakan bahwa pengangkatan komite audit harus dilaksanakan oleh Dewan Direksi yang berlandaskan keputusan rapat Dewan Komisaris, oleh sebab itu, komite audit wajib menjalankan tugasnya secara efisien. (Hassan, 2015) mengatakan dalam teori keagenan (Agency Theory) menunjukkan bahwa komite audit dapat digunakan sebagai pemantauan mekanisme yang meningkatkan kualitas pelaporan perusahaan dan dapat mengurangi asimetri informasi serta mengurangi penyimpangan dan pengungkapan yang tidak dapat diandalkan.

Hasil riset (Anugrah \& Laksito, 2017); (Santiani \& Muliartha, 2018) dan (Afriliana \& Ariani, 2020) mengungkapkan ukuran komite audit berpengaruh 201ariable terhadap Audit Report Lag. Argumen ini didasari karena semakin banyak jumlah anggota komite audit maka semakin mengurangi tingkat Audit Report Lag dan jika anggota komite audit semakin sedikit maka proses Audit Report Lag akan Panjang. Berdasarkan beberapa penelitian terdahulu yang memberikan hasil berbeda-beda diatas sehingga dapat diambil hipotesis.

\section{H3: Ukuran Komite Audit berpengaruh negative Terhadap Audit Report Lag}

\section{METODOLOGI PENELITIAN}

Perusahaan pertambangan adalah populasi yang digunakan dalam penelitan ini sebanyak 41 Perusahaan sektor pertambangan yang terdaftar di BEI periode 20182020 Karena peneliti ingin mengetahui beberapa faktor yang dapat menyebabkan audit report lag pada emiten tersebut. Dari tiga tahun pengamatan dengan 201ariab penarikan sampel adalah purposive maka sampel yang dapat diteliti hanya 24 perusahaan dari tahun 2018 sampai dengan 2020.

\section{Variabel Dependen}

Menurut (Carslaw and Kaplan, 1991; Bamber et al., 1993) dalam Muhammad Rifqi et al, (2019) Audit report lag adalah lamanya hari yang diperlukan untuk menyelesaikan proses audit atas laporan keuangan perusahaan setelah tanggal tutup buku perusahaan. Dalam penelitian ini audit report lag diukur dengan menghitung hari dari tanggal tutup buku sampai dengan tanggal yang tertera pada laporan audit dengan skala variabelnya adalah rasio.

\section{Variabel Independen \\ Rotasi Audit}

Merupakan lamanya hubungan auditor dengan klien, pada penelitian ini audit tenure diukur dengan menghitung lamanya suatu kantor akuntan 201ariab dalam menjalin hubungan secara terus menerus terhadap klien dengan skala 201ariable adalah rasio.

\section{Audit Firm Status}

Menurut Arens et al. (2014) empat kategori ukuran digunakan untuk menggambarkan kantor akuntan 201ariab (KAP) yaitu kantor Internasional Empat Besar, kantor Nasional, kantor Regional atau Kantor Lokal Besar dan kantor Lokal Kecil. Pada penelitian ini audit firm status diukur dengan menggunakan 201ariable 
dummy dimana 1 untuk KAP Big Four dan 0 untuk KAP Non-Big Four dengan skala 202ariable nominal.

\section{Audit Committee}

Anggota yang terpilih dari dewan direktur yang memiliki tanggung jawab untuk membantu auditor dalam menjaga indepedensi di manajemen serta memberi jaminan bahwa laporan keuangan dapat diandalkan dengan 202ariable202 jumlah komite audit yang memiliki kualifikasi akuntansi dan keuangan dan skala 202ariable yang digunakan adalah rasio.

\section{Profitabilitas}

Pengukuran dilakukan dengan menggunakan hasil pengembalian atas ekuitas (ROE). Rasio ini dilakukan untuk menilai kemampuan perusahaan dalam menciptakan laba yang bermodalkan ekuitas yang telah diinvestasikan para pemegang sahamnya. Peneliti memperoleh data berdasarkan laporan keuangan perusahaan. Skala rasio merupakan skala data yang dipergunakan.

\section{Leverege}

Dalam penelitian ini Leverage diukur dengan menggunakan Debt To Equity Ratio (DER), DER digunakan untuk melihat persentase hutang terhadap ekuitas. Dalam penelitian ini Leverage diukur dengan menggunakan Debt To Equity Ratio (DER), DER digunakan untuk melihat persentase hutang terhadap ekuitas. Jika nilai DER $>1$ atau 100\% maka dapat disimpulkan bahwa perusahaan memiliki resiko yang tinggi dalam memenuhi hutang perusahaan.

\section{Model Penelitian}

Penelitian ini menggunakan analisis regresi. Rumus model penelitian ini ditunjukan dalam Rumus 4 dibawah ini

Rumus 4. Model Penelitian

$\mathrm{ARL}_{i \mathrm{t}}=\beta_{0}+\beta_{1} \mathrm{ART}_{\mathrm{it}}+\beta_{2} \mathrm{AFS}_{\mathrm{it}}+\beta_{3} \mathrm{UKA}_{\mathrm{it}}+\beta_{4} \mathrm{ROA}_{\mathrm{it}}+\beta_{5} \mathrm{DER}_{\mathrm{it}}+\varepsilon_{\mathrm{it}} \ldots \ldots \ldots \ldots$ (4)

Keterangan:

$\mathrm{ARL}=$ Audit Report Lag

$\beta_{0} \quad=$ Konstanta

$\beta=$ Koefisien

$\mathrm{ART}=$ Audit rotasi

AFS $=$ Audit Firm Status

UKA = Ukuran Komite Audit

ROA = Profitabilitas pada akhir tahun $\mathrm{t}$

DER = Hutang Jangka Panjang

$\varepsilon=$ Standard Error

\section{HASIL DAN PEMBAHASAN}

Analisiss statistik memiliki fungsi gambaran atau deskripsi suatu data yang dilihat dari nilai minimum, nilai maksimum, mean, dan standar deviasi pada suatu penelitian sehingga informasi yang didapat dalam bentuk ringkas mudah dipahami. Tabel 3 menjabarkan statistik deskriptif atas sampel penelitian. 
Tabel 3. Hasil Uji Statistik Deskriptif

\begin{tabular}{lcccccc}
\hline & ARL & ART & AFS & UKA & ROA & DER \\
\hline Mean & 88.857140 & 2.728571 & 0.495714 & 4.428571 & 26.837830 & 0.086274 \\
Median & 70.000000 & 2.000000 & 0.000000 & 5.000000 & 29.693390 & 0.076724 \\
Maximum & 80.000000 & 7.000000 & 2.000000 & 7.000000 & 33.200960 & 0.470021 \\
Minimum & 36.000000 & 1.000000 & 0.000000 & 2.000000 & 25.655800 & 0.180135 \\
Std. Dev. & 9.630000 & 1.672148 & 0.623405 & 1.773073 & 1.461983 & 0.105392 \\
Observations & 72.000000 & 72.000000 & 72.000000 & 72.000000 & 72.000000 & 72.000000 \\
\hline
\end{tabular}

Sumber: Data diolah penulis (2021)

Tabel di atas memberikan gambaran dari setiap variabel. Berdasarkan dideskripsikan sebagai berikut; Audit Report Lag membuktikan Batasan masimum 80.000000 dan nilai minimum 36.000000 selanjutnya nilai rata - rata dan standar deviasi menunjukan 88.857140 dan 9.630000. Demikian untuk variabel Audit Report Lag mempunyai standar deviasi sebesar 9.630000 maka nilainya jika dibandingkan dengan nilai rata-rata (mean) menunjukan variabel Audit Report Lag memiliki simpangan dan sebaran data yang kecil.

Rotasi Audit dengan menunjukkan nilai maksimum 7.000000 dan nilai minimum 1.000000 sedangkan nilai rata-rata dan standar deviasi menunjukan 2.728571 dan 1.672148. Dapat disimpulkan dari nilai rata-rata tersebut perusahaan sektor pertambangan memliliki waktu perputaran audit.

Audit Firm Status Audit membuktikan batasan maximum 2.000000 serta minimum 0.000000 dan standar deviasi yaitu 0.623405 dan nilai rata-rata 0.495714. Dapat disimpulkan dari nilai rata-rata tersebut perusahaan sektor pertambangan memakai jasa KAP the big four. Ukuran Komite Audit dengan menunjukkan nilai maksimum 7.000000 dan nilai minimum 2.000000 serta ratarata 5.428571 selanjutnya deviasi standar 1.773073 dan. Dapat disimpulkan dari nilai rata-rata tersebut perusahaan sektor pertambangan memiliki komite audit dengan kaulifikasi kompetensi dibidang akuntansi dan keuangan.

Profitabilitas dengan menunjukkan nilai maksimum 33.200960 dan nilai minimum 25.655800 selanjutnya rata-rata 26.837830 dengan deviasi standar sebesar 1.461983. Dapat disimpulkan dari nilai rata-rata tersebut perusahaan sektor pertambangan memiliki tingkat profitabilitas yang diproksikan dengan ROA dengan kemampuan laba yang dimiliki untuk memperoleh aktiva perusahaan.

Leverege dengan menunjukkan maximum value 0.470021 dan nilai minimum 0.180135 dengan nilai mean 0.086274 dan deviasi standar sebesar 0.105392. Dapat disimpulkan dari nilai mean tersebut pada sektor pertambangan mempunyai tingkat Leverege yang diproksikan dengan DER menunjukan adanya kemampuan perusahaan membayar hutang jangka panjangnya.

\section{Analisis Model Penelitian}

Merujuk pada Tabel 4, memberikan informasi nilai Prob. 0.0000 Ha diterima karena $\leq \alpha(5 \%)$ dan $\mathrm{H}_{0}$ ditolak. Dengan demikian model fixed effect yang digunakan sehingga karena itu lanjut ke Hausman Test. 
Tabel 4. Hasil Uji Chow Test dan Hausman Test

\begin{tabular}{cc}
\hline Test Effect & Prob. \\
\hline Cross-section Chi-square & 0.0000 \\
\hline Cross-section Random & 0.9947 \\
\hline
\end{tabular}

Sumber: Data diolah Penulis (2021)

Melihat pada Tabel 5, Ho diterima karena Prob. $0.9947 \geq \alpha(5 \%)$ berarti $\mathrm{Ha}_{\mathrm{a}}$ di Tolak, dengan random effect model yang digunakan.

\section{Hasil Uji Asumsi Klasik}

Jika nilai correlation matrix lebih besar dari 0.8 maka dapat dikatakan bahwa didalam model terdapat unsur multikolinearitas, dan sebaliknya jika nilai correlation matrix lebih kecil dari 0.8 maka dapat dikatakan bahwa didalam model tidak terdapat unsur multikolinearitas atau dapat dinyatakan lolos uji multikolinearitas. Pada penelitian ini hasil Uji Multikolinearitas menunjukan nilai correlation matrix antar variabel inedependen memiliki korelasi dibawah 0.8. sehingga dapat ditarik kesimpulan bahwa dalam model penelitian ini dinyatakan lulus uji dan tidak terdapat unsur multikolinearitas antar variabel independen.

Uji Heterokedastisitas pada penelitian ini dilakukan dengan meregresikan variabel independent terhadap nilai resid. Jika $p$-value lebih dari 0.5 maka dalam data penelitian ini terdapat heterokedastisitas, sebaliknya Jika $p$-value lebih dari 0.5 maka dalam data penelitian ini lolos uji dan tidak terdapat heterokedastisitas. hasil Uji Heterokedastisitas diatas, menunjukan nilai $p$-value setiap variabel lebih dari 0.5 , sehingga dapat ditarik kesimpulan bahwa pada model penelitian ini lolos uji dan tidak terdapat heterokedastisitas.

Uji Heterokedastisitas digunakan untuk melihat apakah ada hubungan antar variabel residual dengan variabel dependen. Untuk mengetahui ada tidaknya Heterokedastisitas dapat menggunakan Uji Glesjer. Probabilitas masing-masing variabel Independen $\geq \alpha(5 \%)$, dengan demikian dinyatakan $\mathrm{H}_{0}$ dari Uji Heterokedastisitas tidak dapat ditolak. Maka dari itu penelitian ini terbebas dari Heterokedastisitas.

\section{Regresi Data Panel}

Interpretasi dari persamaan ini adalah Audit Report Lag (ARL) yang dihasilkan sebesar 93 hari bahwa apabila Rotasi Audit (ART), Audit Firm Status (AFS), Komite Audit (UKA), Profitabilitas (PROF), Leverege (DER) diasumsikan nol. Nilai Koefisien regresi untuk ART sebesar - 0.110478 berarti Audit Report Lag akan berkurang sebesar 0.110478 hari untuk setiap peningkatan satu tahun. Hal tersebut terjadi apabila lainnya diasumsikan nol. Nilai regresi untuk AFS sebesar 2.067968 berarti rata-rata ARL yang menggunakan jasa Big Four lebih cepat 2.067968 hari dibandingkan dengan rata-rata ARL entitas dengan memakai jasa kantor akuntan publik non big four.

Nilai coefisient regresi untuk UKA sebesar -0.470173 berarti Audit Report Lag berkurang 0.470173 jumlah hari dalam tiap tambahan satu orang komite audit demikian juga terjadi apabila variabel lain diasumsikan nol. Nilai koefisien regresi Profitabilitas sebesar 0.391777 berarti Audit Report Lag bertambah pada jumlah 
0.391777 hari disetiap penjumlahan satu satuan Profitabilitas demikian sebaliknya. Hal tersebut terjadi apabila variabel lain diasumsikan nol. Nilai coefisient Leverege adalah 41.93179 berarti Audit Report Lag berkurang sebesar 41.93179 hari untuk setiap peningkatan satu persen Debt-to-Equity demikian sebaliknya ini terjadi apabila variabel lain diasumsikan nol.

Tabel 6. Hasil Uji Regresi

\begin{tabular}{lccc}
\hline \multicolumn{1}{c}{ Variable } & Coefficient & t-Statistic & Prob. \\
\hline C & 93.00328 & 2.019309 & 0.0476 \\
ART (Rotasi Audit) & -0.110478 & -0.173547 & 0.0328 \\
AFS (Audit Firm Status) & 2.067968 & 0.442075 & 0.0299 \\
UKA (Komite Audit) & -0.470173 & -0.267517 & 0.0317 \\
ROA (Profitabilitas) & 0.391777 & 0.228294 & 0,0059 \\
DER (Leverege) & 41.93179 & 2.849674 & 0,8201 \\
\hline R-squared & 0,386479 & & \\
Adjusted R-squared & 0,358547 & & \\
\hline
\end{tabular}

Sumber: Data diolah penulis (2021)

Adapun hasil Regresi linear data panel sebagai berikut:

Rumus 5. Persamaan Regresi Linier

$\mathrm{ARL}_{i, t}=93.00328-0.110478 \mathrm{ART}_{i, t}+2.067968 \mathrm{AFS}_{i, t}-0.470173 \mathrm{UKA}_{i, t}+0.391777$

$\mathrm{ROA}_{i, t}+41.93179 \mathrm{DER}_{i, t}$

Adjusted $R^{2}$ adalah pengujian yang dilakukan untuk menghitung seberapa jauh model memiliki kemampuan dalam menerangkan variasi variabel independent (Ghozali, 2013). Adjusted $R^{2}$ adalah uji yang dilakukan agar dapat mengetahui persentasi dalam variabel dependen yang dijelaskan oleh variabel independen, dari nilai koefisien determinasi (Adjusted R-squared) sebesar 0,358547 atau sebesar $35.8547 \%$. Nilai tersebut diartikan bahwa variabel independen yaitu Rotasi Audit (RA), Audit Firm Status (AFS), Ukuran Komite Audit (UKA) mampu menjelaskan pengaruh terhadap Audit Report Lag sebesar 35,85 \%, sisanya sebesar 64,15\% dipengaruhi oleh faktor lain di luar model penelitian ini.

\section{Hasil Analisis}

\section{Pengaruh Rotasi Audit terhadap Audit Report Lag}

Pada tabel 6, dikatakan Rotasi audit berpengaruh negatif pada ARL. Dapat diartikan keterikatan partner dengan beban kerja yang berat dapat memitigasi dampak buruk dari ketepatan waktu dari melaporkan laporan audit secara tepat waktu ketika mereka memiliki client tenure yang lebih lama, ini berarti rotasi audit berpengaruh Negatif terhadap ARL. Diperkuat dengan hasil penelitian Abdillah et al (2019) dan Simamora \& Hendarjatno (2019) yang menunjukan bahwa terdapat pengaruh Rotasi Audit terhadap Audit Report Lag. Hal ini mempumyai arti Panjang atau pendek perikatan antara perusahaan klien dengan KAP berpengaruh terhadap lamanya KAP dalam mejadikan laporan auditnya. 


\section{Pengaruh Audit Firm Status terhadap Audit Report Lag}

Pada tabel 6, menjelaskanaudit firm status berpengaruh positive terhadap ARL Berarti dalam meningkatkan reputasinya, the big four didampingi para ahli yang memiliki keahlian teknis dan teknologi canggih dibandingkan non-big foaur. KAP yang lebih besar berpengaruh terhadap terjadinya ARL Hal ini menunjukan KAP the big four lebih efisien dalam menyelesaikan pekerjaan auditnya dibandingkan KAP non big four. Hasil ini diperkuat oleh penelitian Rizki dan Basuki (2017) dimana the big four maupun non big four berpengaruh pada ketepatan dalam pelaporan keuangan. Artinya big four maupun non-big four mempengaruhi lamanya KAP dalam meng-audit perusahaan klien.

\section{Pengaruh Komite Audit terhadap Audit Report Lag}

Pada tabel 6, menunjukan komite audit memiliki pengaruh negatif terhadap ARL. Hal ini menunjukan audit comittee bertanggung jawab atas pemantauan terhadap kualitas pelaporan keuangan entitas serta mengurangi penyimpangan dan pengungkapan yang tidak dapat diandalkan. Argumen ini didasari karena semakin meningkat jumlah anggota komite audit maka semakin mengurangi tingkat $A R L$ dan jika anggota komite audit semakin sedikit maka proses $A R L$ akan Panjang. Penelitian ini mendukung penelitian Faishal dan Basuki (2015) dan penelitian Rizki dan Basuki (2017) yang menyatakan bahwa kimite audit berpengaruh negatif terhadap audit report lag. Maka dinyatakan bahwa banyak dan sedikitnya audit commitee tidak akan mempengaruhi lamanya KAP dalam menyampaikan laporan auditnya.

\section{SIMPULAN}

Hasil penelitian ini bertujuan untuk menganalisis berpengaruh Rotasi Audit, Audit Firm Status, serta Komite Audit terhadap Audit Report Lag dengan Leverege dan Profitabilitas Sebagai Variabel Kontrol yang dilakukan pada sektor pertambangan yang terdaftar pada BEI periode 2018-2020. Berdasarkan analisis dan pembahasan meliputi; Variabel Rotasi Audit berpengaruh negatif terhadap audit report lag pada. Hal ini dapat diartikan keterikatan partner dengan beban kerja yang berat dapat memitigasi dampak buruk dari ketepatan waktu dari melaporkan laporan audit secara tepat waktu ketika mereka memiliki client tenure yang lebih lama. Variabel audit firm status berpengaruh positif terhadap audit report lag. Hal ini menujunkan KAP yang lebih besar berpengaruh terhadap terjadinya ARL Hal ini menunjukan KAP the big four lebih efisien dalam menyelesaikan pekerjaan auditnya dibandingkan KAP non big four. Variabel komite audit berpengaruh negatif terhadap audit report lag, hal ini didasari karena semakin meningkat jumlah anggota komite audit maka semakin mengurangi tingkat $A R L$ dan jika anggota komite audit semakin sedikit maka proses $A R L$ akan Panjang.

Penelitian ini telah diusahakan dan dilaksanakan sesuai dengan prosedur ilmiah, namun masih terdapat beberapa keterbatasan yaitu; Pada penelitian ini, penulis hanya berfokus pada tiga variabel independen yaitu Rotasi audit audit firm status, komite audit dan dua variabel kontrol yaitu Leverege dan profitabilitas dalam menggambarkan audit report lag, sedangkan masih banyak variabel-varibel lain yang mampu menggambarkan audit report lag. Dikarenakan adanya pandemik 
Covid-19, hampir seluruh kantor akuntan publik mengalami penurunan performa dalam mengaudit laporan keuangan perusahaan tahun 2020 yang secara langsung dapat mempengaruhi variabel audit report lag. Sehingga audit report lag yang ada pada periode 2020 tergolong lebih besar dibandingkan dengan tahun-tahun sebelumnya. Model yang digunakan dalam penelitian ini hanya dapat menghasilkan adjusted $R$-squared yang tergolong kecil yaitu sebesar 35,85\%, sisanya $64.15 \%$ dipengaruhi oleh faktor-faktor lain di luar model penelitian.

Saran-saran yang dapat diambil dari keterbatasan penelitian ini adalah untuk peneliti selanjutnya, dalam meneliti audit report lag, sebaiknya menjadikan KAP menjadi objek utama dalam penelitian dan menggunakan variabel yang berkaitan dengan KAP, seperti jumlah anggota tim audit, jumlah rapat tim audit dengan klien, kemampuan auditor dalam memahami bisnis klien, dan lain sebagainya. Untuk peneliti selanjutnya juga diharapkan untuk memperhatikan faktor-faktor eksternal yang cakupannya lebih luas seperti perbandingan kurs antar negara, tingkat inflasi, perubahan regulasi dan lain sebagainya.

\section{DAFTAR PUSTAKA}

Abdillah, Muhammad Rifqi, et al, (2019). The Effect of Company Characteristics and Auditor Characteristics to Audit Report Lag. Asian Journal of Accounting Research Vol. 4 No. 1, 2019 pp. 129-144.

Agoes, Soekrisno, (2004). Auditing (pemeriksaan Akuntansi) oleh Kantor Akuntan Publik. Edisi Ketiga, Fakultas Ekonomi Universitas Indonesia. Jakarta.

Agoes, Sukrisno, (2017). Auditing: Petunjuk Praktis Pemeriksaan Akuntan oleh Akuntan Publik. Buku 1, Edisi 5. Jakarta: Salemba Empat.

Anugrah, E., \& Laksito, H. (2017). Pengaruh efektivitas komite audit terhadap ketepatan waktu pelaporan (Studi Empiris Pada Perusahaan Non Keuangan Terdaftar di BEI Tahun 2015). Diponegoro Journal of Accounting, 6(4), 3244.

Arens, et al, (2008). Auditing and Assurance Services: An Integrated Approach. Edisi Dua Belas, Erlangga.

Ariyani, Ni Nyoman Trisna Dewi, (2014). Pengaruh Profitabilitas, Ukuran Perusahaan, Kompleksitas Operasi Perusahaan dan Reputasi Kap terhadap Audit Report Lagpada Perusahaan Manufaktur. E-Jurnal Akuntansi Universitas Udayana 8.2 (2014): 217-230.

Butarbutar, Rizki Sakti Kornelius, dan Hadiprajitno, P. Basuki, (2017). Analisis Faktor-Faktor Yang Berpengaruh Terhadap Audit Report Lag. Diponegoro Journal of Accounting Volume 6, Nomor 3, Tahun 2017, Halaman 1-12.

Carslaw, Charles A.P.N. dan Kaplan, Steven E. (1991). An Examination of Audit Delay: Further Evidence from New Zealand. Accounting and Business Research, Vol. 22. No. 85. pp. 21-32.

Bedard, J.C. and Johnstone, K.M. (2010), "Audit partner tenure and audit planning and pricing", Auditing: A Journal of Practice and Theory, Vol. 29 No. 2, pp. 4570 .

Dewi, Irvional Chyntia, dan Hadiprajitno, P. Basuki, (2017). Pengaruh Audit Tenure dan Kantor Akuntan Publik (KAP) Spesialisasi Manufaktur terhadap Audit 
Report Lag (ARL). Diponegoro Journal of Accounting Volume 6, Nomor 4, Tahun 2017, Halaman 1-12.

Dyer, J. C. I. V., dan A. J. McHugh, (1975). The Timeliness of The Australian Annual Report. Journal of Accounting Research. Autumn. Vol. 13. No.2. Hal: 204- 219.

Effendi, Muh. Arief, (2016). The Power of Good Corporate Governance. Edisi 2. Jakarta: Salemba Empat.

Ettredge, M., Li, C. and Sun, L. (2006), "The impact of SOX Section 404 internal control quality assessment on audit delay in the SOX era", Auditing: A Journal of Practice \& Theory, Vol. 25 No. 2, pp. 1-23.

Faishal, Muhammad, dan Hadiprajitno, P. Basuki, (2015). Pengaruh Mekanisme Good Corporate Governance terhadap Audit Report Lag. Diponegoro Journal of Accounting, Volume 4, Nomor 4, Tahun 2015, Halaman 1.

Fargher, N., Lee, H.Y. and Mande, V. (2008), "The effect of audit partner tenure on client manager's accounting discretion", Managerial Auditing Journal, Vol. 23 No. 2, pp. 161-186.

Ghozali, Imam. 2011. Aplikasi Analisis Multivariate Dengan Program SPSS. Semarang: Badan Penerbit Universitas Diponegoro.

Greuning, Hennie Van, et al, (2013). International financial reporting standards: sebuah panduan praktis. Jakarta: Salemba Empat.

Gujarati, D.N. dan D.C. Porter, (2010). Dasar-Dasar Ekonometrika, Edisi 5. Jakarta: Salemba Empat

Jensen, dan Meckling, (1979). The Theory of The Firm: Manajerial Behavior, Agency Cost, and Ownership Structure. Journal of Financial and Economics.

Juanita, Greta, dan Satwiko, Rutji, (2012). Pengaruh Ukuran Kantor Akuntan Publik, Kepemilikan, Laba Rugi, Profitabilitas dan Slovabilitas Terhadap Audit Report Lag. Jurnal Bisnis dan Akuntansi Vol. 14, No 1, April 2012, HIm,31-40.

Mai Dao, dan Trung Pham, (2014). Audit Tenure, Auditor Specialization and Audit Report Lag. Managerial Auditing Journal Vol. 29 No. 6, 2014 pp. 490-512.

Meckfessel, Michele D., dan Sellers, Drew, (2017). The Impact of Big 4 Consulting on Audit Reporting Lag and Restatements. Managerial Auditing Journal Vol. 32 No. 1, 2017 pp. 19-49.

Masli, A., Peters, G., Richardson, V. and Sanchez, M. (2010), "Examining the potential benefits of internal control monitoring technology", The Accounting Review, Vol. 85 No. 3, pp. 1001-1034.

Michael, Candra Jimmi, dan Abdul Rohman, (2017). Pengaruh Audit Tenure dan Ukuran Kap terhadap Audit Report Lag dengan Spesialisasi Industri Auditor Sebagai Variabel Moderasi. Diponegoro Journal of Accounting, Volume 6, Nomor 4, Tahun 2017, Halaman 1-12.

Nawari. (2010). Analisis Regresi dengan MS Excel 2007 dan SPSS 17. Jakarta: PT. Elex Media Komputindo.

Prastiti, Anindyah, (2013). Pengaruh Karakteristik Dewan Komisaris dan Komite Audit terhadap Manajemen Laba. Skripsi. Semarang. Universitas Diponegoro

Simamora, Rahmat Akbar, dan Hendarjatno, Hendarjatno, (2019). The Effects of Audit Client Tenure, Audit Lag, Opinion Shopping, Liquidity Ratio, And Leverage to The Going Concern Audit Opinion. Asian Journal of Accounting Research Vol. 4 No. 1, 2019 pp. 145-156.

Siwy, Resti Ayu, (2012). Pengujian Empiris Atas Audit Report Lag Pada Perusahaan 
Manufaktur dan Dagang Go Public yang Terdaftar Pada Bursa Efek Indonesia Tahun 2008-2010. Skripsi. Surabaya. STIE PERBANAS.

Sugiyono. 2007. Metode Penelitian Kuantitatif Kualitatif dan R\&D. Bandung: Alfabeta.

Sugiyono, (2012). Metode Penelitian Kuantitatif Kualitatif dan R\&D. Bandung: Alfabeta.

Sugiyono, (2017). Metode Penelitian Kuantitatif, Kualitatif, dan R\&D. Bandung: Alfabeta.

Sutikno, Yosua Martin, dan Hadiprajitno, P. Bauki, (2015). Analisis Faktor Internal dan Eksternal Yang Berpengaruh terhadap Audit Report Lag. Diponegoro Journal ff Accounting Volume 4, Nomor 2, Tahun 2015, Halaman 1-9.

Tambunan, Pinta Uli, (2014). Pengaruh Opini Audit, Pergantian Auditor dan Ukuran Kantor Akuntan Publik terhadap Audit Report Lag. Skripsi. Padang. Universitas Negri Padang.

Wan Hussin, Wan Hussin, et al, (2018). Lead Engagement Partner Workload, Partner-Client Tenure and Audit Reporting Lag Evidence from Malaysia. Managerial Auditing Journal Vol. 33 No. 3, 2018 pp. 246-266.

Widhiasari, Ni Made Shinta, dan Budiartha, I Ketut, (2016). Pengaruh Umur Perusahaan, Ukuran Perusahaan, Reputasi Auditor, dan Pergantian Auditor terhadap Audit Report Lag. E-Jurnal Akuntansi Universitas Udayana Vol.15.1. April (2016): 200-227.

Independent Regulatory Board of Auditor (IRBA).

Peraturan Menteri Keuangan Nomor: 17/PMK.01/2008.

Peraturan Otoritas Jasa Keuangan Nomor 29/POJK.04/2016.

Peraturan Otoritas Jasa Keuangan Nomor 33 /POJK.04/2014.

Pernyataan Standar Akuntansi Keuangan 1 Tahun 2014 "Penyajian Laporan Keuangan"

Undang-undang No. 5 Tahun 2015 “Akuntan Publik 
EQUITY, Vol. 24, No.2, 2021, 193-210

Halaman ini sengaja dikosongkan untuk kepentingan penggenapan halaman 